\title{
NFKB1 regulates human NK cell maturation and effector functions
}

\author{
Vassilios Lougaris $^{\mathrm{a}, *}$, Ornella Patrizi ${ }^{\mathrm{b}}$, Manuela Baronio ${ }^{\mathrm{a}}$, Giovanna Tabellini ${ }^{\mathrm{b}}$, Giacomo Tampella ${ }^{\mathrm{a}}$, \\ Eufemia Damiati ${ }^{a}$, Natalie Frede ${ }^{c}$, Jos W.M. van der Meer ${ }^{\mathrm{d}}$, Manfred Fliegauf ${ }^{\mathrm{c}}$, Bodo Grimbacher $^{\mathrm{c}}$, \\ Silvia Parolini ${ }^{\mathrm{b}}$, Alessandro Plebani ${ }^{\mathrm{a}}$ \\ a Pediatrics Clinic and Institute for Molecular Medicine A. Nocivelli, Department of Clinical and Experimental Sciences, University of Brescia, Spedali Civili di Brescia, Italy \\ b Department of Molecular and Translational Medicine, University of Brescia, Italy \\ c Center for Chronic Immunodeficiency (CCI), Medical Center, Faculty of Medicine, University of Freiburg, Germany \\ d Radboud University Medical Centre, Department of Internal Medicine, Nijmegen 6525, HP, The Netherlands
}

\section{A R T I C L E I N F O}

Article history:

Received 8 July 2016

Received in revised form 4 November 2016

Accepted with revision 24 November 2016

Available online 3 December 2016

\section{Keywords:}

NFKB1

Natural killer cells

Cytotoxicity

Interferon- $\gamma$

\begin{abstract}
A B S T R A C T
NFKB1, a component of the canonical NF- $K B$ pathway, was recently reported to be mutated in a limited number of CVID patients. CVID-associated mutations in NFKB2 (non-canonical pathway) have previously been shown to impair NK cell cytotoxic activity. Although a biological function of NFKB1 in non-human NK cells has been reported, the role of NFKB1 mutations for human NK cell biology and disease has not been investigated yet. We decided therefore to evaluate the role of monoallelic NFKB1 mutations in human NK cell maturation and functions. We show that NFKB1 mutated NK cells present impaired maturation, defective cytotoxicity and reduced IFN- $\gamma$ production upon in vitro stimulation. Furthermore, human IL-2 activated NFKB1 mutated NK cells fail to upregulate the expression of the activating marker NKp44 and show reduced proliferative capacity. These data suggest that NFKB1 plays an essential novel role for human NK cell maturation and effector functions.
\end{abstract}

(c) 2016 Elsevier Inc. All rights reserved.

\section{Introduction}

The NF-кB (NF-kappaB; nuclear factor of kappa light polypeptide gene enhancer in $\mathrm{B}$ cells) signaling pathway plays an important role both in the innate and the adaptive immune system [1-3]. The NF- $\kappa B$ transcription factor family consists of five members: NF- $\kappa$ B1, NF- $\kappa \mathrm{B} 2$, RelA, RelB and c-Rel. NFKB1 encodes the precursor p105 which is processed to the mature p50. NFKB2 encodes the precursor p100 and the mature p52. The canonical pathway, which includes NFKB1, mediates numerous immunological and inflammatory cellular responses, and may be activated upon stimulation with a broad range of stimuli, including proinflammatory cytokines, activation of innate immune receptors, T-cell receptor (TCR) and B-cell receptor (BCR) signaling, and others [1-3]. The non-canonical pathway, which involves NFKB2, has more restricted immunological functions mainly focusing on B cell homeostasis

Abbreviations: NFKB1, Nuclear Factor kappa-B, subunit 1; CVID, Common Variable Immunodeficiency; NFKB2, Nuclear Factor kappa-B, subunit 2; NK cells, natural killer cells; IFN- $\gamma$, Interferon-gamma; MFI, mean fluorescence intensity; IL-2, Interleukin-2; IL12, Interleukin 12; IL-18, Interleukin 18; CMV, Cytomegalovirus; EBV, Epstein Barr Virus; JCV, Poliomavirus JC.

* Corresponding author at: Pediatrics Clinic and Institute of Molecular Medicine "A. Nocivelli", Department of Clinical and Experimental Sciences, University of Brescia, Piazzale Spedali Civili 1, 25123 Brescia, Italy.

E-mail address: vlougarisbs@yahoo.com (V. Lougaris). and is activated upon engagement of a limited set of members of the TNF receptor superfamily, including BAFF receptor, CD40 and the lymphotoxin receptor [2-4].

Data on the NF- $\kappa B$ involvement in NK cell function and maturation are limited. The first indirect description of the biological role of NF- $\kappa \mathrm{B}$ in NK cells was derived from in vitro pharmacological NF- $\kappa B$ inhibition that led to impaired NK cell cytotoxicity [5]. Studies on Interleukin-2 (IL-2) induced NK cell functional stimulation have implicated the activation of NF- $\kappa \mathrm{B}$ in both, cytotoxic activity and production of Interferon-gamma (IFN- $\gamma$ ) [6]. However, most of these studies did not investigate the role of individual components of the NF- $\kappa \mathrm{B}$ signaling pathway. Observations in $N f k b 1$-deficient mice suggested that p50 is a negative regulator of NK cell proliferation and IFN- $\gamma$ production [7].

Primary immunodeficiencies provide unique opportunities for a better understanding of the human immune system. For instance, congenital mutations in NIK [8] or NEMO [9], both of which encode upstream components of the NF- $\kappa B$ pathways, have demonstrated their importance for NK cell function. Monoallelic mutations in NFKB2, causing a functional haploinsufficiency due to expression of unprocessable p100 precursors have been reported in CVID patients [10-11] and were shown to impair NK cell cytotoxic activity [12]. Recently, monoallelic mutations in NFKB1 leading to p50 haploinsufficiency have also been reported in three CVID families [13]. However, the impact of these NFKB1 mutations in human NK cell biology has not been investigated. In the present study, we analyzed NK cell 
Table 1

Clinical information of the 7 NFKB1 mutated CVID patients.

\begin{tabular}{|c|c|c|c|c|c|c|c|c|c|}
\hline Patient ID & Nationality & Sex & $\begin{array}{l}\text { Year of } \\
\text { birth }\end{array}$ & $\begin{array}{l}\text { Year of } \\
\text { diagnosis }\end{array}$ & $\operatorname{IgG} G^{a}$ & $\operatorname{Ig} A^{a}$ & $\operatorname{IgM}^{a}$ & Clinical features & Viral infections \\
\hline Patient 1 [14] & Italian & M & 1976 & 1989 & 160 & 10 & 10 & $\begin{array}{l}\text { Recurrent pulmonary infections, autoimmune thyroiditis, } \\
\text { autoimmune enteropathy, gastric adenoma }\end{array}$ & No EBV, CMV, HBV, HCV (PCR neg.) \\
\hline $\begin{array}{l}\text { Patient } 2^{\mathrm{b}, \mathrm{c}} \\
(\text { Fam191_02) }\end{array}$ & German & $\mathrm{F}$ & 1961 & $\begin{array}{l}1994 \\
(2008)\end{array}$ & $\begin{array}{l}670 \\
(251)\end{array}$ & $\begin{array}{l}30 \\
(<6)\end{array}$ & $\begin{array}{l}30 \\
(<16)\end{array}$ & $\begin{array}{l}\text { Pneumonias, necrotizing tonsillitis, autoimmune cytopenia } \\
\text { (ITP, intermittent leukopenia, anemia), splenomegaly, } \\
\text { lymphadenopathy, interstitial lung disease, periodontitis, } \\
\text { multiple liver hemangiomas }\end{array}$ & $\begin{array}{l}\text { Herpes zoster }(2 \text { episodes }) \\
\text { CMV viremia }(8500 \mathrm{IE} / \mathrm{ml}) \text { with CMV colitis treated } \\
\text { with valganciclovir; intermittent low grade } \\
\text { EBV + CMV replication }\end{array}$ \\
\hline $\begin{array}{l}\text { Patient } 3^{\mathrm{b}, \mathrm{c}} \\
\text { (Fam191_01) }\end{array}$ & German & M & 1963 & 2006 & 8 & 5 & 5 & $\begin{array}{l}\text { Recurrent sinusitis, recurrent otitis, pneumonia, salmonella enteritis, } \\
\text { autoimmune cytopenia, vitiligo, arthritis, splenomegaly, } \\
\text { lymphadenopathy, granulomatous lung disease, persistent CRP elevation }\end{array}$ & $\begin{array}{l}\text { Herpes zoster ( } 3 \text { episodes) } \\
\text { No EBV, CMV, HBV (PCR neg.); adenovirus + respiratory } \\
\text { virus panel for respiratory infections neg. }\end{array}$ \\
\hline $\begin{array}{l}\text { Patient } 4[13] \\
\text { (FamNL1-36) }\end{array}$ & Dutch & $\mathrm{F}$ & 1961 & 1991 & 181 & 6 & 48 & Recurrent sinusitis, pneumonia, otitis media, severe salmonella enteritis & n.a. \\
\hline $\begin{array}{l}\text { Patient } 5[15] \\
\text { (Fam089II2) }\end{array}$ & German & $\mathrm{F}$ & 1979 & $\begin{array}{l}1995 \\
(2006)\end{array}$ & $\begin{array}{l}629 \\
(441)\end{array}$ & $\begin{array}{l}<30 \\
(<7)\end{array}$ & $\begin{array}{l}<30 \\
(2)\end{array}$ & $\begin{array}{l}\text { Recurrent pulmonary infections, ITP, autoimmune hemolytic anemia, } \\
\text { hepatomegaly, lymphadenopathy }\end{array}$ & $\begin{array}{l}\text { Herpes zoster ( } 2 \text { episodes) } \\
\text { No EBV, CMV, HBV, HCV, HIV, HHV8 (PCR neg.); enteritis } \\
\text { virus panel for chronic diarrhoea neg. }\end{array}$ \\
\hline $\begin{array}{l}\text { Patient } 6[15] \\
\text { (Fam830_01) }\end{array}$ & German & M & 1956 & 2003 & 270 & $<6$ & 21 & $\begin{array}{l}\text { Chronic sinusitis, recurrent otitis, pneumonia, skin abscesses, } \\
\text { atopic dermatitis with fungal superinfections, autoimmune enteropathy, } \\
\text { nodular regenerative hyperplasia, splenomegaly, lymphadenopathy, } \\
\text { thrombocytopenia }\end{array}$ & $\begin{array}{l}\text { JC virus encephalitis } \\
\text { Norovirus2 infection with intermittent bloody diarrhoea } \\
\text { Herpes zoster ( } 2 \text { episodes) } \\
\text { EBV reactivation with } 1000 \text { copies/ml, no specific therapy, }\end{array}$ \\
\hline $\begin{array}{l}\text { Patient } 7^{\mathrm{c}} \\
\text { (Fam695_01) }\end{array}$ & German & $\mathrm{F}$ & 1957 & $\begin{array}{l}1987 \\
(2014)\end{array}$ & $\begin{array}{l}\text { n.a. } \\
(462)\end{array}$ & $\begin{array}{l}\text { n.a. } \\
(6)\end{array}$ & $\begin{array}{l}\text { n.a. } \\
(15)\end{array}$ & $\begin{array}{l}\text { Recurrent bronchitis and sinusitis, enteropathy, splenomegaly, basal } \\
\text { cell carcinoma, osteoporosis }\end{array}$ & No EBV, CMV, HBV, HCV (PCR neg.) \\
\hline
\end{tabular}

Numbers in brackets indicate follow-up examinations.

n.a. not available.

Patients 2 and 3 are siblings.

Expressed in $\mathrm{mg} / \mathrm{dl}$.

Not previously described patients. 
maturation and effector functions in patients with NFKB1 mutations affecting the canonical NF- $\kappa$ B pathway.

\section{Methods}

\subsection{Monoclonal antibodies}

The fine characterization of surface markers of resting and IL-2 activated NK cells was performed using the following monoclonal antibodies (mAbs) generated in our laboratory (Department of Molecular and Translational Medicine, University of Brescia), or in the laboratory directed by A. Moretta (Laboratory of Molecular Immunology, DIMES, University of Genoa): BAB281 (IgG1, anti-NKp46); AZ20 (IgG1, antiNKp30); ON72 (IgG1, anti-NKG2D); C127 and SUS142 (IgG1 and IgG2b respectively, anti-CD16); C227 (IgG1, anti-CD69); 11PB6 (IgG1, anti-KIR2DL1/S1); GL183 (IgG1, anti-KIR2DL2/L3/S2); AZ158 (IgG2a, anti-KIR3DL1/S1/L2); Z199 (IgG2b, anti-CD94/NKG2A); anti-XA147 (IgM, anti-CD57); A6/136 (IgM anti-HLA-I).

The commercially available antibodies used in this study are: anti-CXCR1 (IgG1, Santa Cruz biotechnologies, Santa Cruz, CA; USA); anti-NKG2C (IgG2b R\&D Systems, MN, USA); anti-hCCR7 (IgG2a R\&D Systems, MN, USA); anti-CD62L (IgG1 R\&D Systems, MN, USA); anti-CD107a PE-labeled; anti-IFN- $\gamma$ PE- (IgG1, BD-Biosciences, Pharmingen CA, USA); mixture of FITC-labeled CD3 plus PC5-labeled CD56, FITC-labeled CD14 and FITC-labeled CD20 (Beckman Coulter, Immunotech, Marseille, France); anti-human Ki-67 antigen (IgG1, Dako, Denmark A/S); Annexin V PE (BD-Biosciences, Pharmingen CA, USA); anti-human Perforin/R-PE (Ancell) and anti-human Granzyme/ R-PE (Enzo-Life Sciences).

\subsection{Patients, cell preparations and flow cytometry analysis}

Seven (7) CVID patients harboring monoallelic NFKB1 mutations were included in this study (Table 1). Since Patients 2 and 3 are siblings and carry the same NFKB1 mutation (Table 1), and due to limitation of biological material available, only one of the two patients was included in each set of experiments. Peripheral blood mononuclear cells (PBMCs) derived from patients and healthy donors, were obtained from heparinized or EDTA blood by density gradient centrifugation over Ficoll (Sigma, St. Louis, MO). PBMCs were resuspended in RPMI 1640 medium, supplemented with $2 \mathrm{mM}$ glutamine, $50 \mu \mathrm{g} / \mathrm{ml}$ penicillin, $50 \mu \mathrm{g} / \mathrm{ml}$ streptomycin and 10\% heat-inactivated FCS (Fetal Calf Serum, Sigma, St. Louis, MO).

To obtain polyclonal NK cell lines, NK lymphocytes were isolated from PBMCs using negative selection (NK cell isolation Kit, Miltenyi), then cultured on allogenic irradiated feeder cells in the presence of $600 \mathrm{IU} / \mathrm{ml}$ recombinant human IL-2 (Proleukin; Chiron) and $1.5 \mathrm{ng} / \mathrm{ml}$ phytohemagglutinin (GIBCO Ltd) [14].

To perform flow cytometry analysis, PBMCs and IL-2 activated NK cells derived from peripheral blood were first stained with appropriate primary monoclonal mouse antibodies, followed by PE-conjugated isotype-specific goat anti-mouse secondary reagent (Southern Biotechnology, Birmingham, AL); cells were subsequently stained with a mixture of FITC-labeled CD3 and PC5-labeled CD56, and FITC-labeled CD14 and FITC-labeled CD20. NK cells analysis by flow cytometry was performed by gating on $\mathrm{CD}_{56}{ }^{+} \mathrm{CD} 3^{-} \mathrm{CD} 14^{-}$and $\mathrm{CD} 20^{-}$cells. Cell acquisition was performed on a FACSCanto flow cytometer, and data analyzed using the Diva software (Becton Dickinson, Mountain View, CA).

For Annexin V staining, IL-2 activated NK lymphocytes were resuspended in $1 \times$ Binding Buffer (BD Biosciences) at $1-5 \times 106 / \mathrm{ml}$ and stained with $5 \mu \mathrm{l}$ of fluorochrome-conjugated Annexin V PE to $100 \mu \mathrm{l}$ of cell suspension. Analysis of Annexin $\mathrm{V}$ was performed by gating on $\mathrm{CD}_{56}{ }^{+} \mathrm{CD}^{-}$cells. Cells were analyzed on a FACSCanto (BD Biosciences).

\subsection{Analysis of NK cell degranulation and IFN- $\gamma$ production}

For degranulation assay against human erythroleukemia cell line K562, PBMCs derived from patients and from healthy donors were incubated with or without $600 \mathrm{IU} / \mathrm{ml}$ rh-IL-2 (Proleukin; Chiron) at $37{ }^{\circ} \mathrm{C}$ overnight. Then, samples were co-incubated with target cells at a ratio of 1:3 (K562), in a final volume of $200 \mu \mathrm{l}$ in round-bottomed 96-well plates at $37{ }^{\circ} \mathrm{C}$ and $5 \% \mathrm{CO}_{2}$ for $3 \mathrm{~h}$ in culture medium supplemented with anti-CD107a-PE mAb. After $1 \mathrm{~h}$ of co-incubation, GolgiStop (BD Biosciences Pharmingen, San Diego, CA, USA) was added at a 1:100 dilution. Surface staining was done by incubating the cells with anti-CD3, antiCD14, anti-CD20 and anti-CD56 mAbs for $30 \mathrm{~min}$ at $4{ }^{\circ} \mathrm{C}$. Cells were washed and analyzed by flow cytometry (FACSCanto, Becton Dickinson). Analysis of NK cells was made on $\mathrm{CD}_{5} 6^{+} \mathrm{CD} 3^{-} \mathrm{CD} 14^{-} \mathrm{CD} 20^{-}$gated cells.

To detect intracellular production of IFN- $\gamma$, PBMCs derived from patients and from healthy donors were incubated overnight at $37^{\circ} \mathrm{C}$ with IL12 (20 ng/ml, Peprotech) plus IL18 (100 ng/ml, Peprotech). Cells were then washed, fixed and permeabilized with Cytofix/Cytoperm kit (BD Biosciences Pharmingen). IFN- $\gamma$ production was detected by subsequent intracellular staining with anti-IFN- $\gamma$-PE antibody (BD Biosciences Pharmingen) upon gating on $\mathrm{CD}_{5} 6^{+} \mathrm{CD} 3^{-} \mathrm{CD} 14^{-} \mathrm{CD} 20^{-}$cells. For both degranulation and IFN- $\gamma$ expression experiments, the percentage of positive cells was calculated subtracting the baseline CD107a or IFN- $\gamma$ expression in controls cultures in the absence of stimuli (target cells or cytokines).

\subsection{Analysis of cellular proliferation}

Cellular proliferation of IL 2 activated NK cells from patients' and healthy donors' peripheral blood was evaluated by detecting intracellular
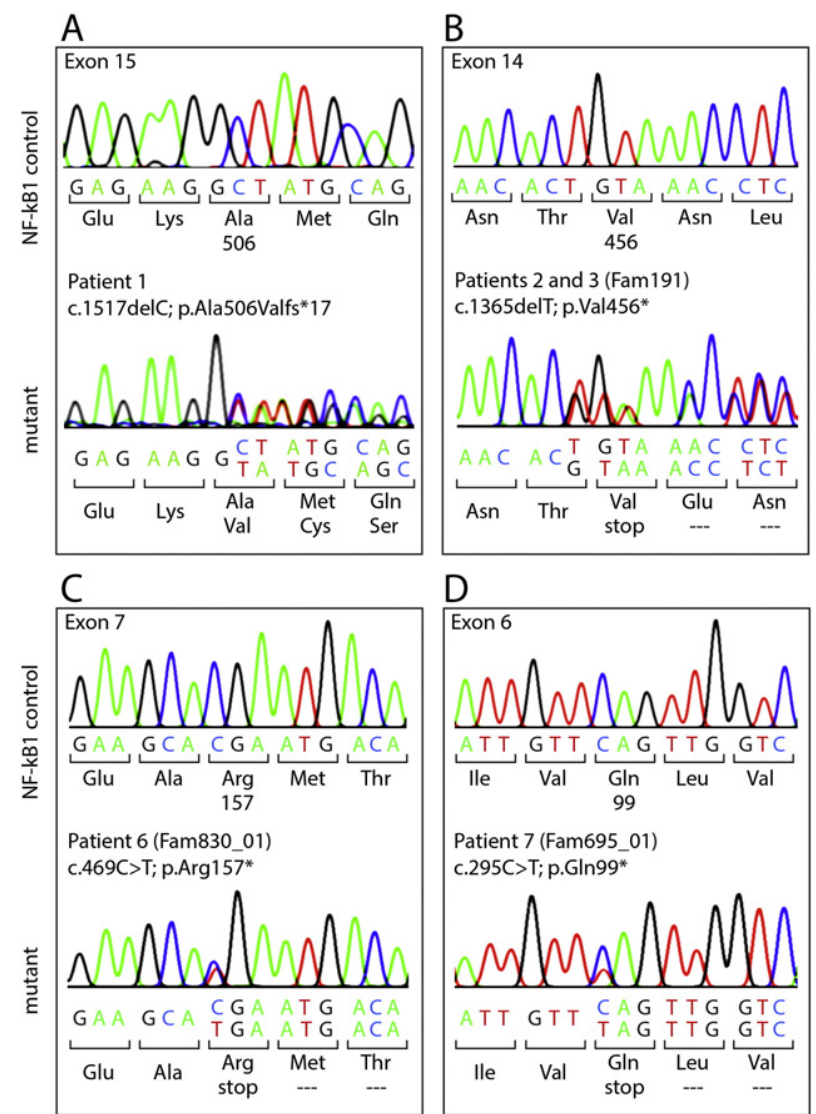

Fig. 1. Novel NFKB1 mutations in adult CVID patients. Electropherograms showing the novel monoallelic null NFKB1 mutations for Patient 1 (A), Patients 2 and 3 (siblings) (B), Patient 6 (C) and Patient 7 (D). Wild type control sequences for the novel NFKB1 monoallelic mutations are shown in the upper panels. 

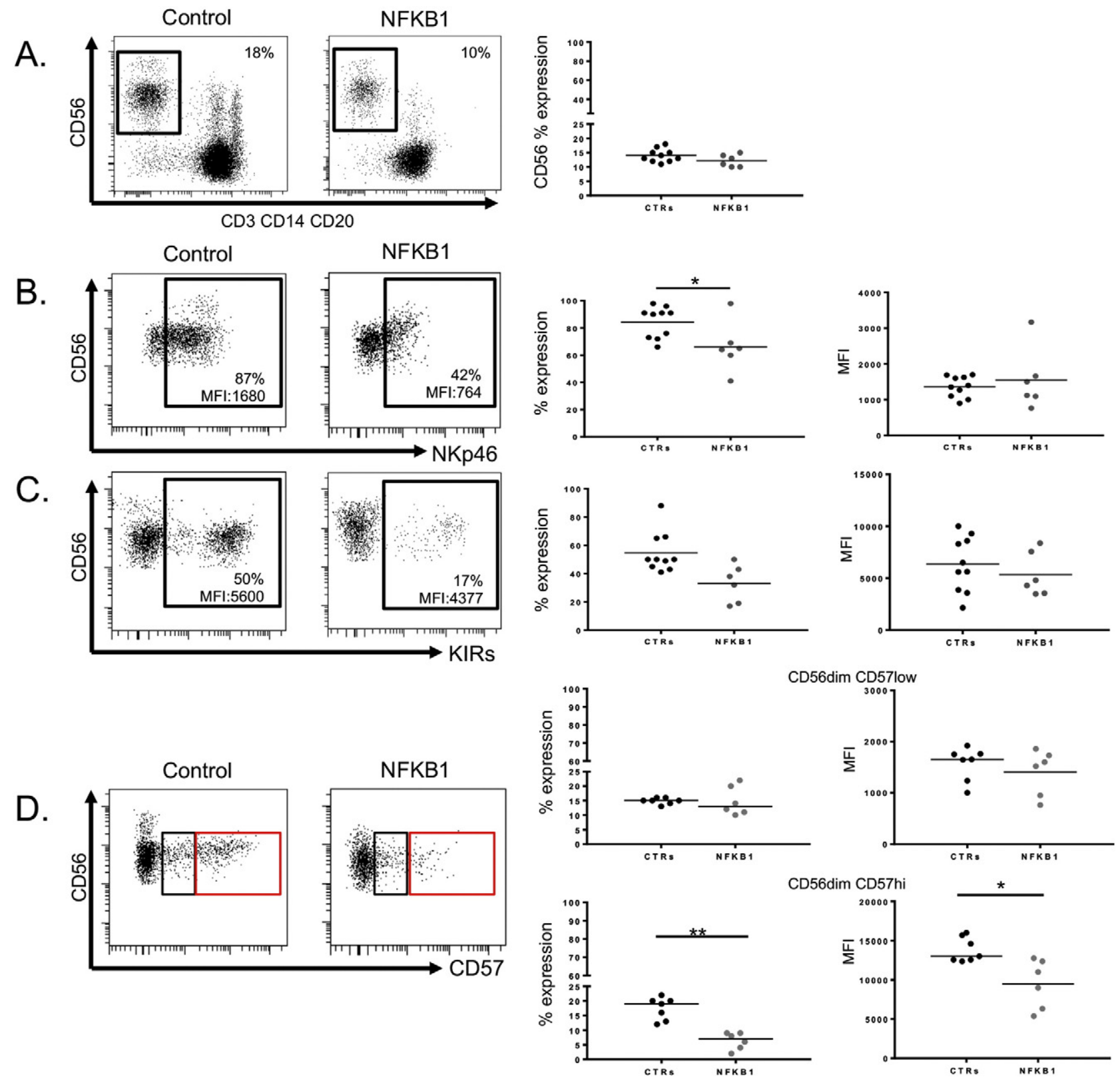

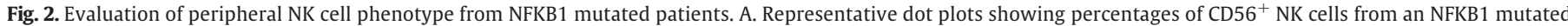

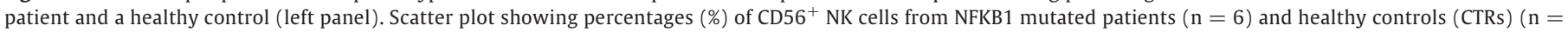

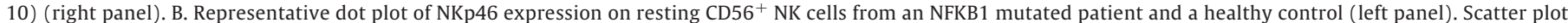

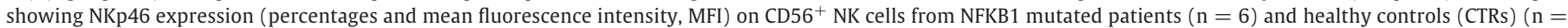

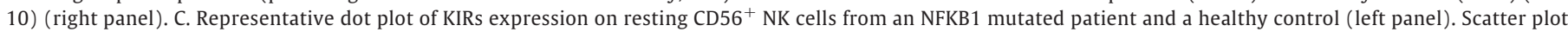

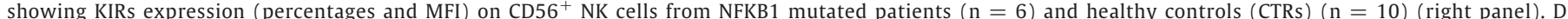

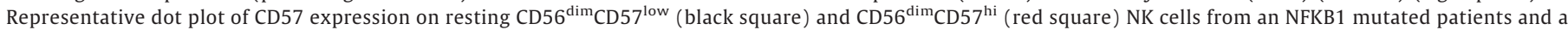

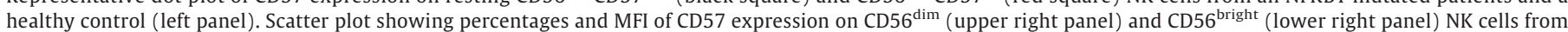

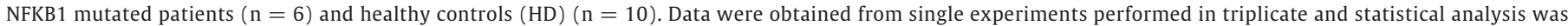
performed using the $t$-student test $\left(^{*}=\mathrm{p}<0,05\right.$; $\left.^{* *}=\mathrm{p}<0,005\right)$.

Ki-67. Polyclonal NK-cell lines were permeabilized with saponin solution $\left(0.1 \%\right.$ in PBS) at $4{ }^{\circ} \mathrm{C}$ for 20 min. Then cells were incubated with $\mathrm{Ki}-67$ $\mathrm{mAb}$ as primary antibody (IgG1, mouse anti-human, 1/40 dilution; Dako, Copenhagen, Denmark) for $1 \mathrm{~h}$ at $4{ }^{\circ} \mathrm{C}$, to detect the nuclear proliferation antigen. The secondary antibody used was PE-conjugated isotype-specific goat anti-mouse (Southern Biotechnology, Birmingham, AL) and was incubated for $30 \mathrm{~min}$ at $4{ }^{\circ} \mathrm{C}$, then cells were re-suspended in $500 \mu \mathrm{l}$ of PBS solution for flow cytometry analysis.

\subsection{Mutational analysis}

Affected individuals were screened with targeted next generation sequencing for mutations in known and prospective genes associated with primary immunodeficiencies as previously described [13]. Sequence variants were verified by Sanger sequencing on genomic DNA according to standard procedures. 


\subsection{Statistical analysis}

Statistical significance was analyzed with the unpaired Student's $t$ test by using GraphPad Prism Version 8.0 (GraphPad Software, San Diego, CA).

\section{Results}

\subsection{Patients and novel NFKB1 mutations}

Seven adult patients affected with CVID carrying monoallelic NFKB1 mutations were included in this study. Table 1 summarizes their clinical and immunological features. All patients presented with recurrent respiratory infections, both of the upper and the lower respiratory tract. None of the patients presented a history of mycobacterial disease. Lymphadenopathy and splenomegaly is a frequent feature of this cohort of patients ( $4 / 7$ and $4 / 7$ patients, respectively). Autoimmune manifestations appeared as prominent features of these NFKB1 mutated patients (6/7 patients) and include autoimmune cytopenias (3/7) and autoimmune enteropathy (3/7). Interestingly, 4 out of 7 patients presented a history of herpes zoster infection, a clinical complication that has not been reported in patients with NFKB1 mutations. Furthermore, Patient 2 presented high grade Cytomegalovirus (CMV) replication with CMV colitis and low grade Epstein Barr Virus (EBV) replication (Table 1). Patient 6 suffered from Poliomavirus JC (JCV) encephalitis, intestinal norovirus infection and EBV reactivation (Table 1).

Two of the affected individuals (Patients 4 and 5) were previously reported in the first description of NFKB1 mutations in CVID [13]. The remaining five patients harbor novel monoallelic NFKB1 mutations (Fig. 1A-D). In detail, Patient 1 harbors a novel frameshift mutation in exon 15 (c.1517delC) [14], which predicts expression of a truncated protein (p.Ala506Valfs*17) Patients 2 and 3 are siblings and harbor a nonsense mutation in exon 14 (c.1356delT), leading to a premature termination of translation (p.Val456*). Both, Patient 6 (c.496C > T; p.Arg157*) [15] and Patient 7 (c.295C > T; p.Gln99*) carry nonsense mutations in exon 7 and exon 6, respectively, predicting rapid decay of the severely truncated proteins and thus, p50 haploinsufficiency.

\subsection{Impaired human NK cell maturation in the presence of monoallelic NFKB1 mutations}

To determine whether monoallelic mutations in NFKB1 affect NK cell maturation, PBMCs from the index patients were evaluated by multicolor flow cytometry. All patients presented normal proportions of circulating CD56 NK cells (Fig. 2A). The evaluation of the expression pattern of activating and inhibitory NK cell receptors, including CD16, Natural Cytotoxicity Receptors (NCRs) (NKp46, NKp30), KIRs (Killer cell Immunoglobulin-like Receptors, HLA class I specific receptors), NKG2A (inhibitory receptor), NKG2C (activating receptor), CD62L (cell adhesion molecule), CD57 and chemokine receptors (CXCR1, CCR7) on human NK cells (both CD56 $6^{\text {bright }}$ and CD56 $6^{\text {dull }}$ subsets) allowed us to discriminate NK cell subsets based on their maturational and functional status [16]. Precisely, while the percentage of CD56 ${ }^{+}$NK cells expressing the NCR NKp30 was similar between patients and controls (Supplementary Fig. 1), the percentage of $\mathrm{CD}^{2} 6^{+}$NK cells expressing the NCR NKp46 was significantly reduced in patients carrying NFKB1 mutations when compared to healthy controls (Fig. 2B). Similar results were obtained when the expression of KIRs on patients' NK cells was evaluated: Patients with NFKB1 mutations showed reduced percentages of $\mathrm{CD}_{56}{ }^{+}$NK cells expressing KIRs when compared to healthy controls (Fig. 2C). The expression of CD57, a classical NK maturation marker [17], showed an interesting pattern (Fig. 2D). The percentages and the mean fluorescence intensity (MFI) for the CD56 ${ }^{\mathrm{dim}} \mathrm{CD} 57^{\text {low }} \mathrm{NK}$ cell population were similar in both test groups (Fig. 2D, upper right panels). In contrast, the CD56 ${ }^{\mathrm{dim}} \mathrm{CD} 57^{\text {hi }} \mathrm{NK}$ cell population was significantly reduced in affected individuals with NFKB1 mutations when compared to healthy controls, both in terms of percentages and MFI (Fig. 2D, lower right panels).

CD62L belongs to the selectin family proteins and represents an additional marker for human NK cell maturation [17]. The expression of this marker on NFKB1 mutated NK cells showed an accumulation of

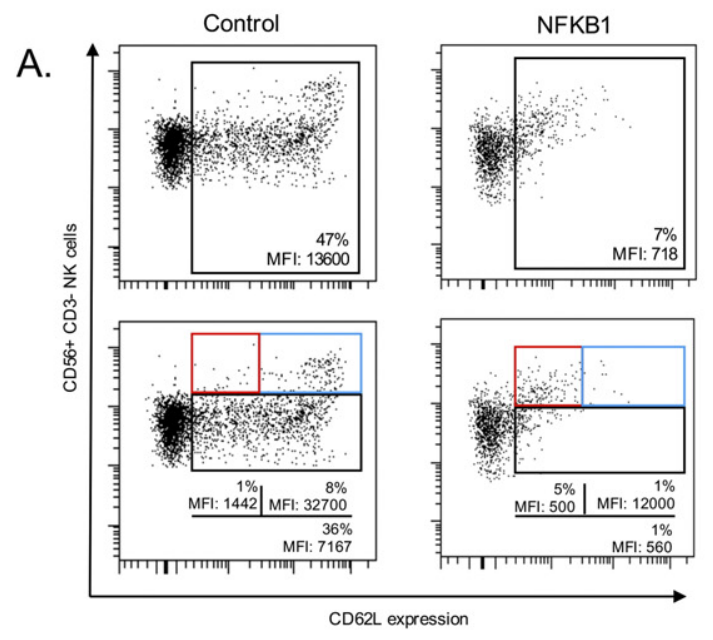

B.

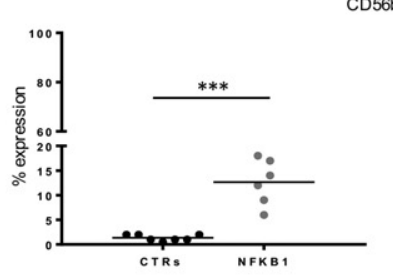

CD56bright CD62Llow (Red)
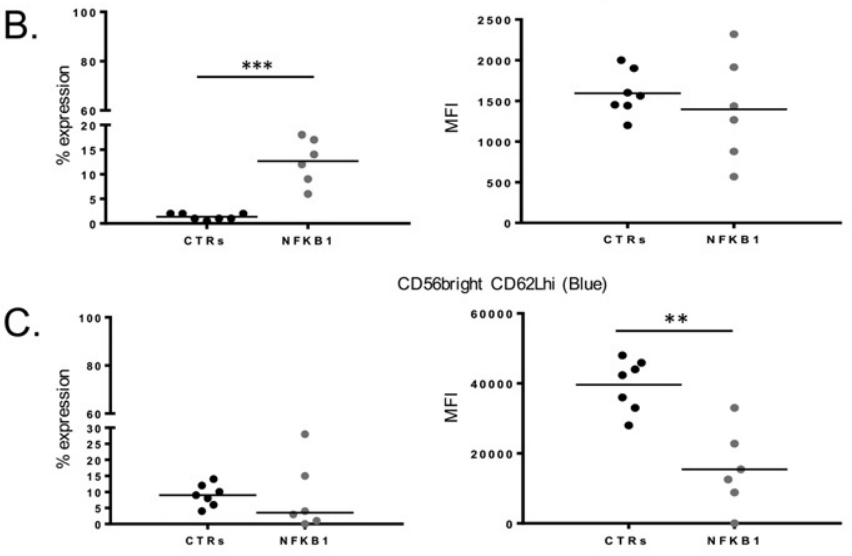

CD56bright CD62Lhi (Blue)

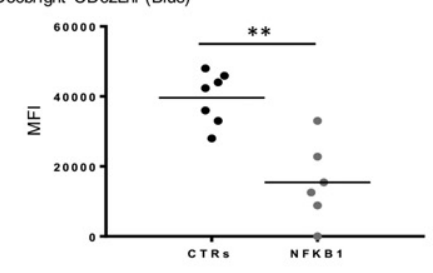

D.

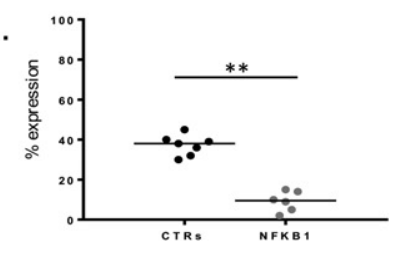

CD56dim CD62L+ (Black)

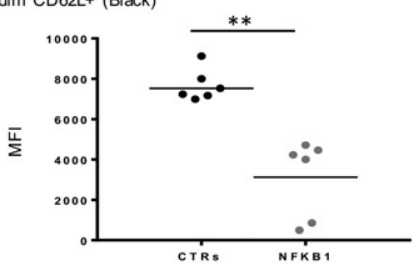

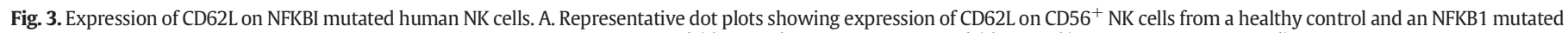

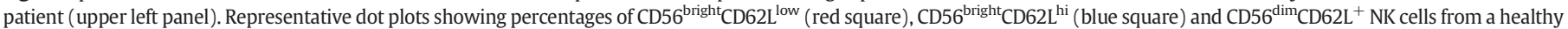

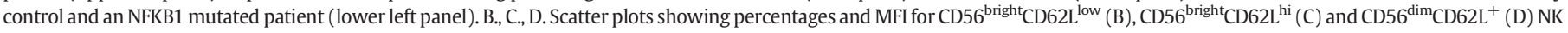

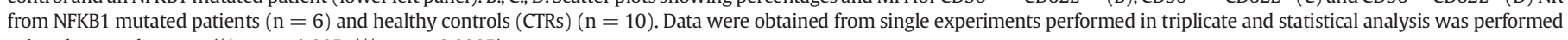
using the $t$-student test $\left(^{* *}=\mathrm{p}<0,005 ;^{* * *}=\mathrm{p}<0,0005\right)$. 

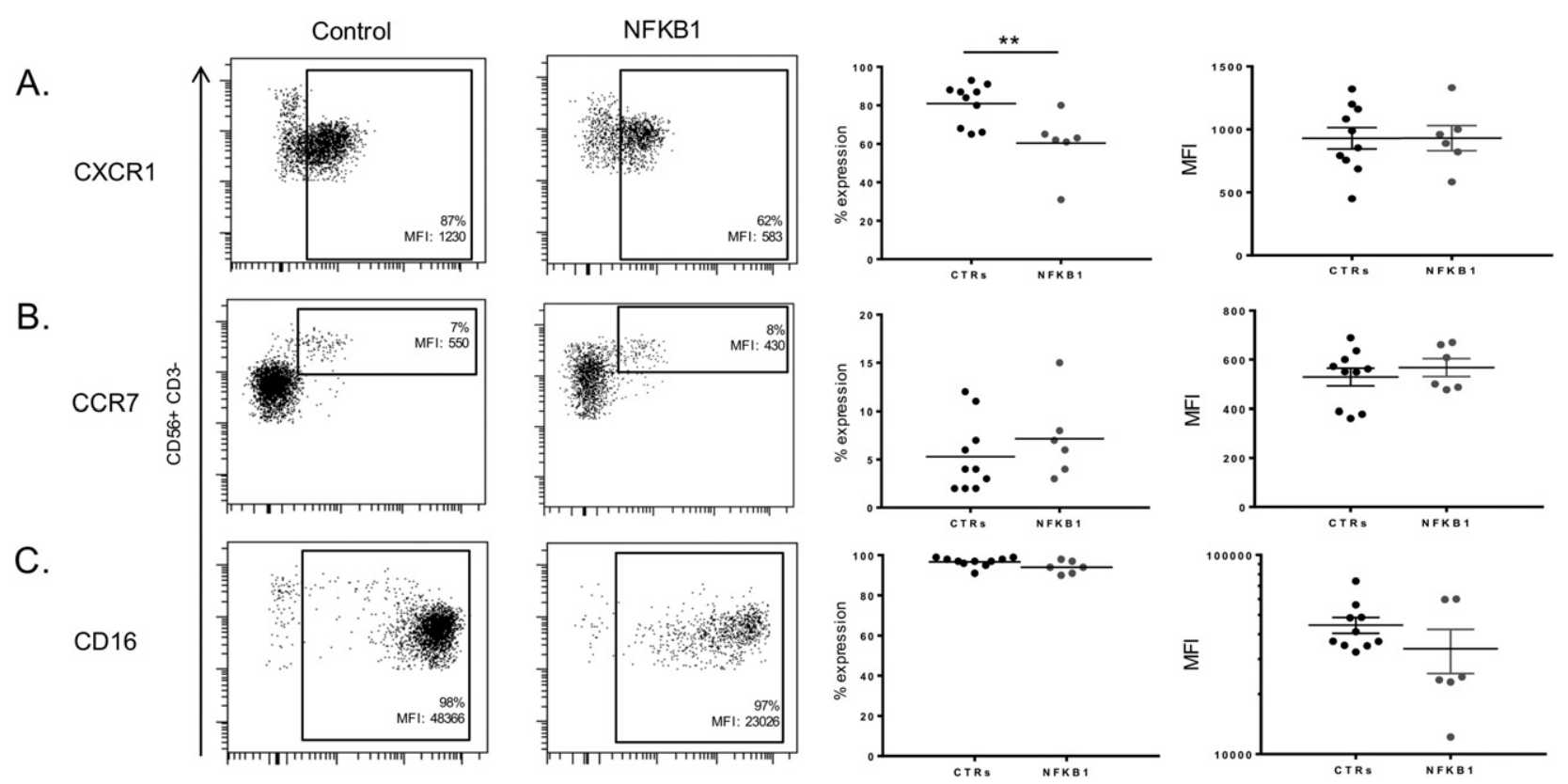

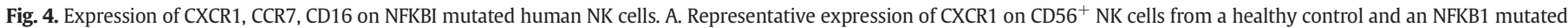

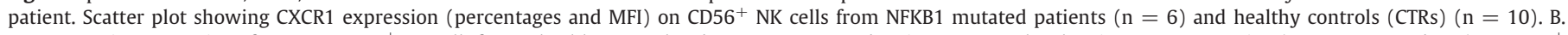

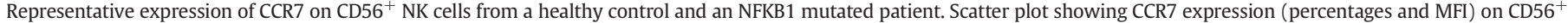

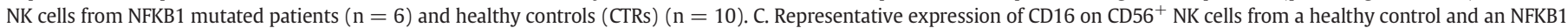

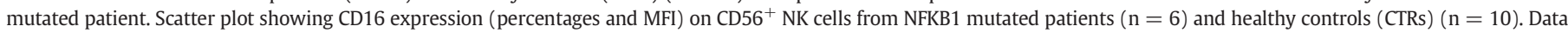
were obtained from single experiments performed in triplicate and statistical analysis was performed using the $t$-student test $\left({ }^{* *}=\mathrm{p}<0,005\right)$.

CD56 ${ }^{\text {bright }} \mathrm{CD} 62 \mathrm{~L}^{\text {low }} \mathrm{NK}$ cells, a finding that was not observed in healthy controls (Fig. $3 \mathrm{~A}$ and B). The proportion of the $\mathrm{CD} 56^{\text {bright }} \mathrm{CD} 62 \mathrm{~L}^{\text {hi }}$ population among the NK cells with NFKB1 mutations was variable when compared to healthy controls; however, the MFI of CD62L within this subset was significantly lower in NFKB1 mutated patients when compared to healthy controls (Fig. 3A and C). Furthermore, the $\mathrm{CD}_{56}{ }^{\mathrm{dim}}{ }_{\mathrm{CD}} 62 \mathrm{~L}^{+}$subset was strongly reduced in NK cells from patients with NFKB1 mutations when compared to healthy controls, both in terms of percentages and MFI (Fig. 3A and D). These data suggest that the canonical NF- $k B$ pathway orchestrates unique aspects of human NK cell maturation stages.

Evaluation of activating (CD16) and chemokine (CXCR1, CCR7) receptors further revealed the involvement of the canonical pathway in human peripheral NK cell maturation/homeostasis (Fig. 4). The percentage of CD56 ${ }^{\mathrm{dim}} \mathrm{NK}$ cells expressing CXCR1 were significantly reduced in NFKB1 mutated patients as compared to healthy controls (Fig. 4A). The percentage of CD56 ${ }^{\text {bright }}$ NK cells expressing CCR7 (Fig. 4B) was variable among the NFKB1 mutated patients, similarly as observed in the healthy controls. The percentages of CD56 ${ }^{+} \mathrm{NK}$ cells expressing CD16 were similar between NFKB1 mutated patients and healthy controls (Fig. 4C). Interestingly, CD16 showed reduced MFI in patients with NFKB1 mutations compared to the healthy controls (Fig. 4C). The expression of the remaining NK cell receptors was normal (Supplementary Fig. 1). In summary, these data provide evidence for an essential role of NFKB1 in human NK cell maturation.

\subsection{Impaired in vitro degranulation of NK cells derived from patients with NFKB1 mutations}

Our results indicated that NK cell maturation was perturbed in the presence of monoallelic NFKB1 mutations. Based on previous published data from mice studies [7] and on our previous observations in NK cells derived from a patient with a heterozygous NFKB2 mutation [12], we next investigated the functional consequences of NFKB1 mutations in human NK cell biology. Baseline degranulation against the human erythroleukemia cell line K562, measured as CD107a expression of resting NK cells [18], was similar in both test groups (NFKB1: 19.33\% mean value, $\mathrm{n}=6$; healthy controls: $24.12 \%$ mean value, $\mathrm{n}=10$ ) (Fig. 5 A upper panel and B). Upon IL-2 stimulation in vitro (Fig. 5A lower panel and 5B), NK cell degranulation against the human erythroleukemia cell line K562 was significantly reduced in cells carrying NFKB1 mutations (44.66\%; $\mathrm{n}=6$; $\mathrm{p}<0.005)$ when compared to healthy controls $(60.71 \% ; \mathrm{n}=10)$. These data collectively provide evidence for a novel role for the canonical pathway in human NK cell degranulation similar to the previously described involvement of the non-canonical pathway [12].

\subsection{NK cells fail to produce Interferon- $\gamma$ in the presence of monoallelic NFKB1 mutations}

Based on our findings on the implication of the canonical NF- $k B$ pathway in human NK cell maturation and degranulation, as well as on studies in p50 deficient mice [7], we next investigated whether IFN- $\gamma$ production, a prominent biological feature of NK cells, was also affected due to the presence of monoallelic NFKB1 mutations. We thus evaluated the production of IFN- $\gamma$ in NK cells derived from patients with NFKB1 mutations and age-matched healthy control donors upon simultaneous stimulation with IL-12 plus IL-18 [19]. As expected, unstimulated NK cells (Fig. 5C upper panel and 5D) in either test group did not produce IFN- $\gamma$ (NFKB1: $11 \%$, mean value, $\mathrm{n}=6$; healthy donors: $8 \%$, mean value, $\mathrm{n}=10$ ). However, upon combined stimulation with IL12 and IL18 (Fig. 5C lower panel and D), IFN- $\gamma$ production was significantly reduced in NK cells from patients carrying NFKB1 mutations $(32.43 \%$, mean value, $\mathrm{n}=6, \mathrm{p}<0.001$ ) when compared to age-matched healthy control samples (72.83\%, mean value, $\mathrm{n}=10$ ). These results collectively suggest that NFKB1 plays a critical, previously unrecognized, role in IFN- $\gamma$ production upon in vitro NK cell stimulation with IL-12 and IL-18.

3.5. IL-2 activated NK cells from patients with NFKB1 mutations fail to upregulate the activation marker $N K p 44$ and display impaired proliferative capacity

Since NK cells derived from individuals carrying NFKB1 mutations had an aberrant receptor profile expression as well as impaired 
A.

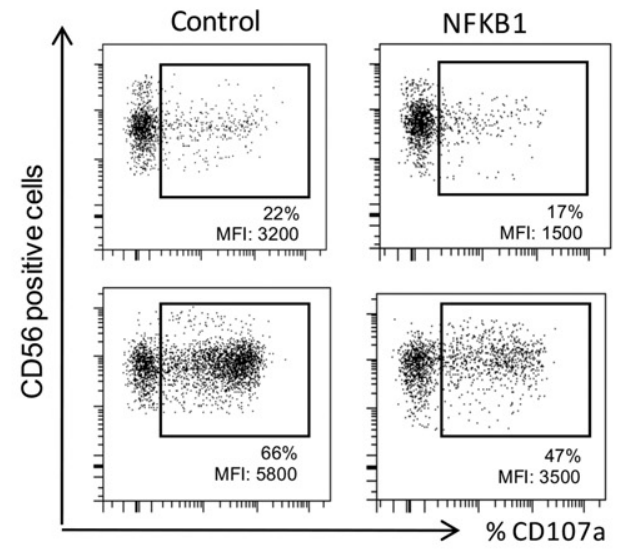

C.

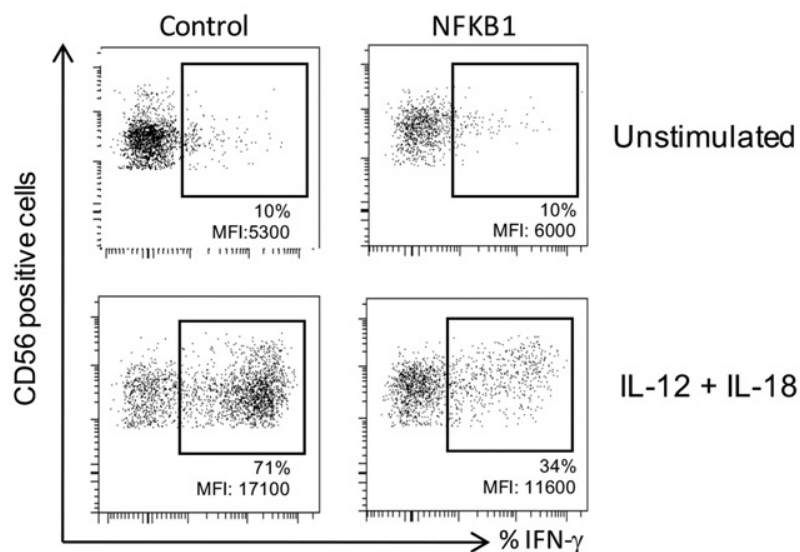

B.

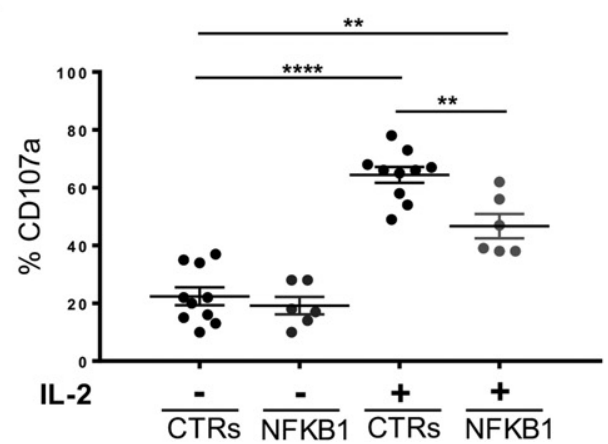

K562

$\mathrm{K} 562+\mathrm{IL}-2$

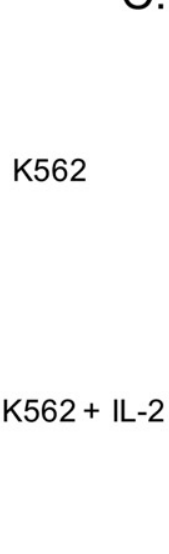

D.

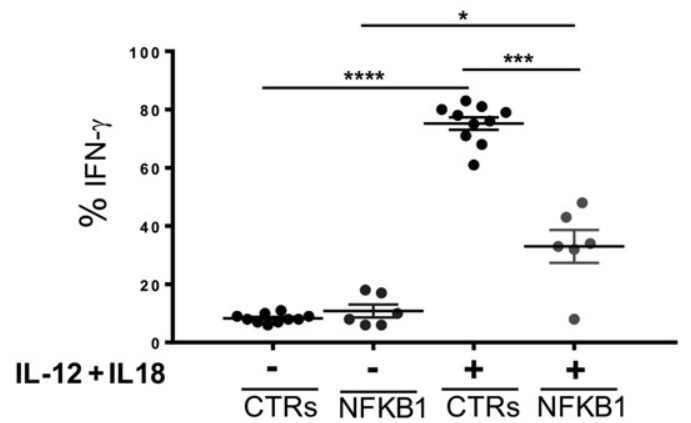

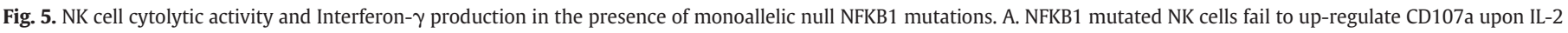

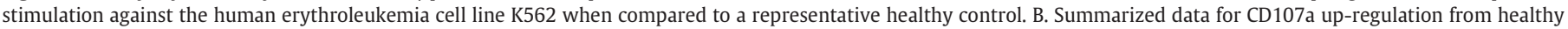

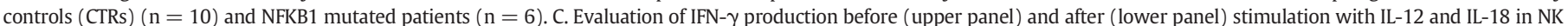

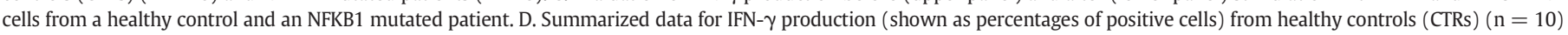

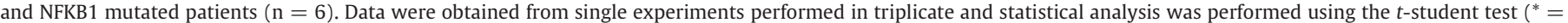
$\left.\mathrm{p}<0,05 ;^{* *}=\mathrm{p}<0,005 ;{ }^{* * *}=\mathrm{p}<0,0005 ;^{* * * *}=\mathrm{p}<0,0001\right)$.

in vitro degranulation and IFN- $\gamma$ production, we also tested whether IL-2 activated NK cell populations showed phenotypical or functional alterations. We therefore evaluated the expression of the NK cell activating receptor NKp44, a member of the NCR family together with NKp46 and NKp3020. Expression of NKp30 in both, resting (Supplementary Fig. 1) and IL-2 activated NK cells (data not shown) was normal in all analyzed samples. In contrast, the expression of the activating receptor of NKp44 on IL-2 stimulated NK cells from patients with NFKB1 mutations was strongly reduced and remained persistently lower over a 4 weeks observation period (time points of evaluation: 14,21 and 28 days) when compared to the controls (Fig. 6A). The expression of NKp46, another member of the NCR family [20], was reduced in unstimulated NK cells from patients with NFKB1 mutations (Fig. 2B), and remained unaffected upon IL-2 stimulation after 21 days of IL-2 stimulation (Fig. 6B), suggesting that the canonical NF-kB pathway plays a distinct role on the expression of activation markers, such as NKp44, on human NK cells.

We furthermore evaluated the intracellular expression of Ki-67 as an index of the proliferative capacity of IL-2 activated NK cells derived from patients with NFKB1 mutations and healthy controls. The proliferative responses upon IL-2 activation of NK cells harboring NFKB1 mutations were impaired as compared to healthy controls (Fig. 6C). The decreased response was not related to cell apoptosis (Fig. 6D) and surface expression levels of IL2R were normal (data not shown). These observations suggest the involvement of NFKB1 in IL-2 dependent human NK cell proliferative response.

\section{Discussion}

The two NF- $\kappa$ B pathways, canonical and non-canonical, play an important role in immune cell biology. Although diverse in terms of components and type of activating stimuli, both pathways have been shown to play crucial roles in distinct biological functions of immune cells [1-3]. This diversity has been studied mainly in mouse models and mainly for B and T lymphocytes [1,4]. Data on the involvement of NF$\kappa B$ in NK cell function and maturation are limited. Regarding the NFKB1-dependent canonical pathway, studies in p50-deficient knockout mice suggested that p50 is a negative regulator of NK cell proliferation and IFN- $\gamma$ production [7]. However, little is known about the involvement of NFKB1 in human NK cell biology in terms of maturation and effector functions. In the present study, we analyzed NK cells derived from patients with mutations in NFKB1 as an "experimentum naturae" model and provide the first evidence for an essential role for NFKB1 in human NK cell biology.

Human NK cell maturation appeared to be impaired in the presence of monoallelic NFKB1 mutations. Whereas patients with NFKB1 mutations showed normal numbers of peripheral NK cells, mutant NK cells showed reduced expression of NKp46, KIRs and CD57. Regarding CD57 in particular, a classical maturation marker [17], while the CD56 ${ }^{\text {dim }} \mathrm{CD}^{2} 7^{\text {lo }}$ NK cell subset occurred normal, NK cells with NFKB1 mutations presented a significant reduction of the $\mathrm{CD} 56^{\mathrm{dim}} \mathrm{CD} 57^{\mathrm{hi}}$ population when compared to healthy controls. Previously published data [21-22] have shown that high CD57 expression levels, co-expressed 
A.

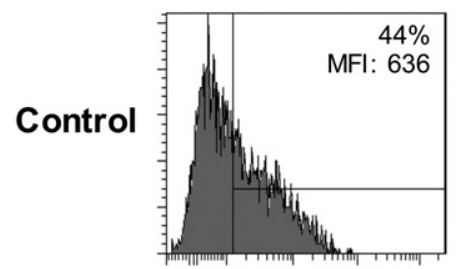

NFKB1

Pt.2

n.a.

C.

NFKB1

Pt.1

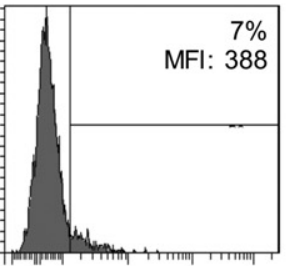

NKp44

Control

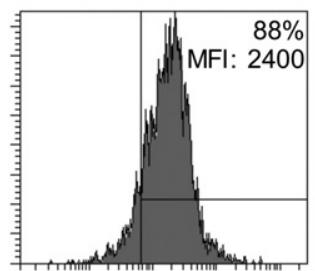

$14 d$

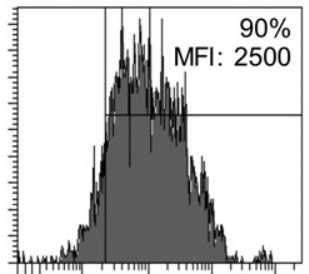

Ki-67 21d
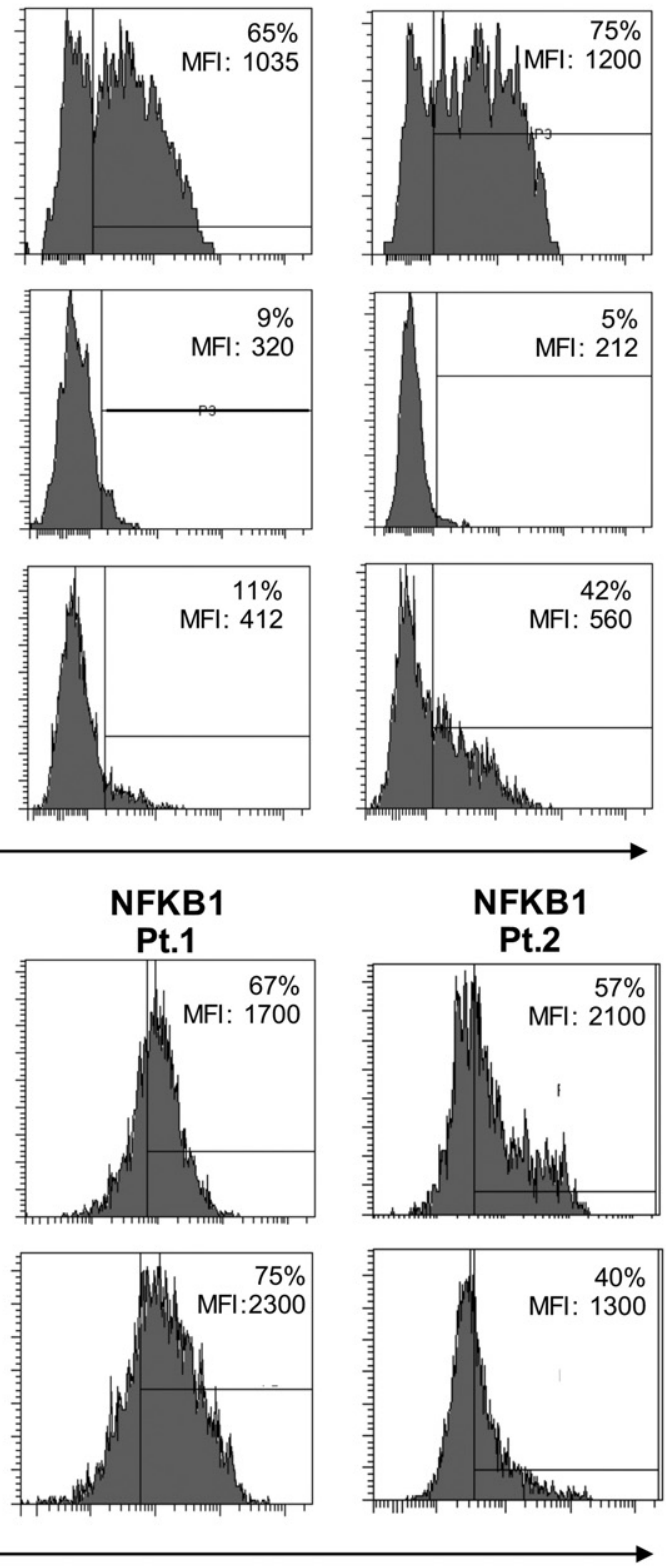

B.

D.
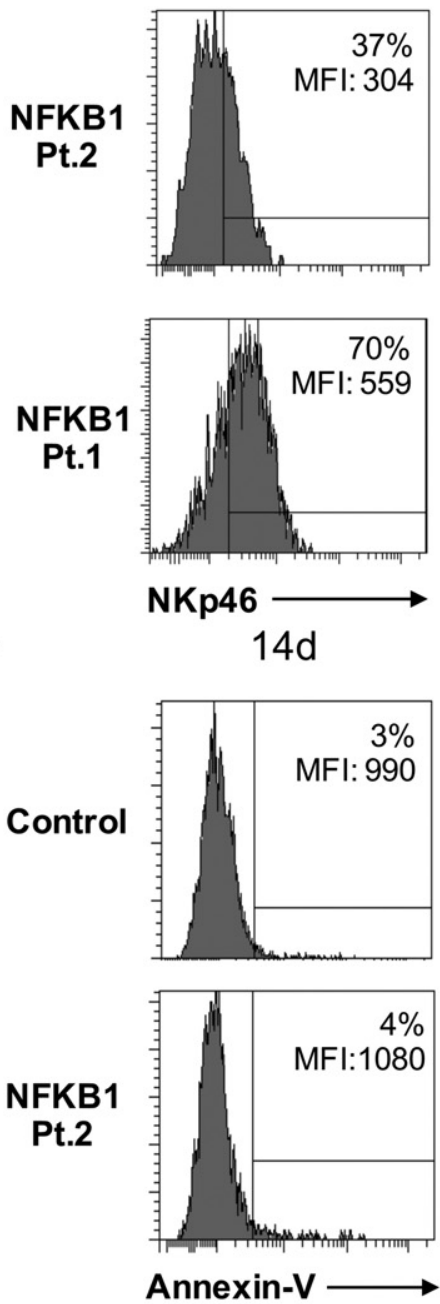

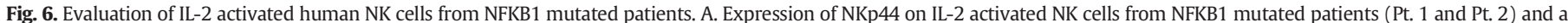

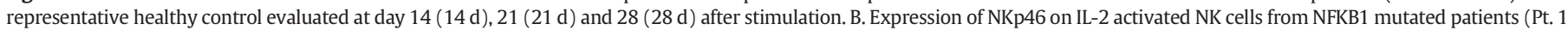

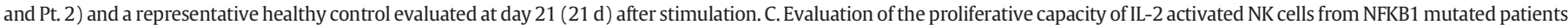

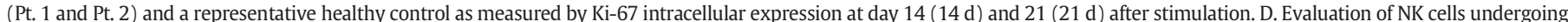

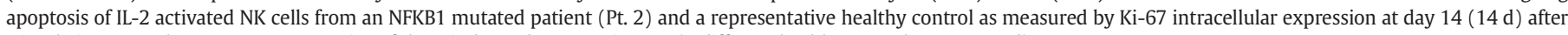
stimulation. Data shown are representative of three independent experiments (3 different healthy controls were tested).

with NKG2C, on CD56 ${ }^{\text {dim }}$ NK cells, define a terminal maturational step for CD56 ${ }^{\mathrm{dim}} \mathrm{NK}$ cells and depict a human viral memory NK cell subset, which lacks in NK cells derived from patients with mutations in NFKB1. Exposure to CMV has been shown to up-regulate CD57 and NKG2C on human NK cells [23-24]. Within this cohort of patents, only one patient presented an infection from CMV. Thus, while the majority of the patients included in this study (6/7) resulted negative for CMV infection, it is not yet known whether the viral infections that were documented in the NFKB1 mutated patients, i.e. herpes zoster (4/7), JC virus $(1 / 7)$, Norovirus $(1 / 7)$ or EBV (2/7), may up-regulate the above mentioned markers in human NK cells. These observations underline a direct and specific role for the canonical pathway in this maturation step of human NK cells.
The chemokine receptors on NK cells with heterozygous NFKB1 mutations showed variable expression of CCR7, but clearly reduced expression of CXCR1 and CD62L. Regarding the latter, NK cells from patients with NFKB1 mutations showed an expansion of the $\mathrm{CD} 56^{\text {bright }} \mathrm{CD} 62 \mathrm{~L}^{\text {low }}$ subset and a severe reduction of the $\mathrm{CD}^{2} 6^{\mathrm{dim}} \mathrm{CD} 62 \mathrm{~L}^{+}$subset when compared to healthy controls. This particular subset of $\mathrm{CD} 56^{\mathrm{dim}} \mathrm{CD} 62 \mathrm{~L}^{+}$ NK cells has been well studied [25] and represents an intermediate stage of NK cell maturation with multiple functional capacities that can develop into terminally differentiated effectors with elevated capability of IFN- $\gamma$ production [25]. Therefore, these data provide further evidence for a specific involvement of the canonical NF- $\kappa B$ signaling in human NK cell maturation that may also underlie defective IFN- $\gamma$ production. 


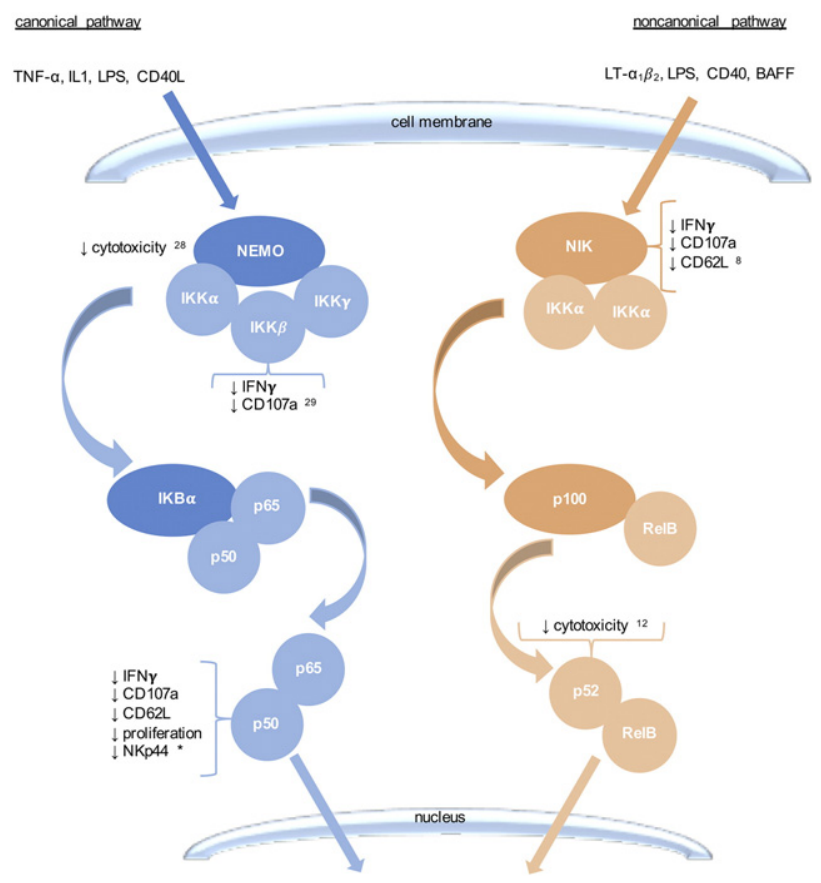

Fig. 7. Summary of NK cell defects in primary immunodeficiencies (PIDs) due to mutations in components of the NF-kB pathway. The asterisk $\left({ }^{*}\right)$ refers to the data presented in the current study.

NK cell degranulation against the K562 target cell line was impaired in IL-2 stimulated NK cells derived from affected patients with NFKB1 mutations. These findings indicate an important role for NFKB1 in this process in humans, similarly to what we observed in human NK cells with defective NFKB2-dependent signaling [12].

Stimulation of NK cells from affected patients with IL12 plus IL-18 in vitro, resulted in impaired production of IFN- $\gamma$, hence revealing another important regulatory role for NFKB1 in human NK cell biology. This functional impairment may be related to the reduction of the $\mathrm{CD} 56{ }^{\mathrm{dim}} \mathrm{CD} 62 \mathrm{~L}^{+}$NK cell population [25] which we observed in patients carrying NFKB1 mutations. Interestingly, the defective IFN- $\gamma$ production of NFKB1 mutated NK cells is in contrast with observations in the p50-deficient knockout mice [7], which show enhanced IFN- $\gamma$ responses, suggesting differences between patients with heterozygous NFKB1 mutations and mice with complete loss of both $N f k b 1$ alleles.

Further evaluation of IL-2 dependent human NK cell responses showed that NK cells with heterozygous NFKB1 mutations failed to up-regulate NKp44, an important member of the NCR family, suggesting that the canonical pathway contributes to IL-2 induced human NK cell activation. The reduced proliferative capacity observed upon in vitro stimulation of NK cells with IL-2, is in contrast with observations in p50-deficient mice [7], and points toward involvement of the canonical NF- $\kappa$ B pathway in IL-2-dependent NK cell activation and reveals further differences between the patients carrying heterozygous NFKB1 mutations and mice with complete loss of both alleles.

Available data on the clinical presentation and possible complications of CVID patients harboring NFKB1 mutations are limited [13]. Besides an increased proportion of autoimmune multiorgan manifestations, which is consistent with observations in p50-deficient mice [26], our cohort of patients with heterozygous NFKB1 mutations presents with an increased prevalence of viral infections, including herpes zoster, JC virus, CMV, Norovirus and EBV, a finding which has previously not been described and which may indicate a broader susceptibility to viral infections in this disorder. Recently, another patient with NFKB1 haploinsufficiency was recently reported with EBV-driven lymphoproliferation, further suggesting a susceptibility to viral infections in NFKB1 mutated patients [27].
Taken together, our findings define a novel intrinsic role for NFKB1 in human NK cell maturation and effector functions. Furthermore, our data broaden the spectrum of NF- $\kappa$ B related PIDs with NK cell defects (Fig. 7) and indicate that longer follow-up examinations and larger cohorts of patients are required for a better characterization of the clinical implications of human NK cell impairment in the presence of heterozygous NFKB1 mutations.

\section{Conclusions}

In this study, we provide evidence that monoallelic NFKB1 mutations affect human NK cell homeostasis in terms of maturation and effector functions. NFKB1 mutated NK cells showed impaired peripheral maturation with a significant reduction of the $\mathrm{CD} 56^{\mathrm{dim}} \mathrm{CD} 57^{\mathrm{hi}}, \mathrm{CD} 56^{\mathrm{dim}} \mathrm{CD} 62 \mathrm{~L}^{+}$ NK cell subsets, as well as altered expression pattern of NKp46, KIRs, CXCR1, CCCR7 and CD16. Furthermore, NFKB1 mutated NK cells showed functional impairments in terms of cytotoxicity, IFN- $\gamma$ production, NKp44 up-regulation and proliferation. From a clinical point of view, NFKB1 haploinsufficient patients show a high prevalence of viral infections. Taken together, our data suggest an important, novel role for NFKB1, thus for the canonical NF-kB pathway, in human NK cell biology and human disease.

Supplementary data to this article can be found online at http://dx. doi.org/10.1016/j.clim.2016.11.012.

\section{Funding}

The research leading to these results has received funding from the European Community's Seventh Framework Programme FP7/20072013 under grant agreement no 201549 (EURO-PADnet HEALTH-F22008-201549) and from the Italian Ministerial Grant GR-20102315762. The research leading to these results also received funding from the "Fondazione C. Golgi", Brescia, Italy and Associazione Immunodeficienze Primitive (A.I.P.). This study was supported by the German Federal Ministry of Education and Research (BMBF 01E01303).

\section{Acknowledgments}

We would like to thank Fondazione Camillo Golgi, Brescia, Italy and Associazione Immunodeficienze Primitive (A.I.P.). We would also like to thank Alessandro Moretta for providing monoclonal antibodies anti-NK cells receptors, produced in the Laboratory of Molecular Immunology, DIMES, University of Genoa, Italy. We would also like to thank the patients, the patients' families and the nurses for all their efforts. We thank Katrin Hübscher and Jessica Rojas-Restrepo for excellent technical assistance.

\section{References}

[1] S. Gerondakis, R. Grumont, R. Gugasyan, L. Wong. I. Isomura, W. Ho, A. Banerjee, Unravelling the complexities of the NF-kappaB signalling pathway using mouse knockout and transgenic models, Oncogene 25 (51) (Oct 30 2006) 6781-6799.

[2] M.S. Hayden, S. Ghosh, NF-kB, the first quarter century: remarkable progress and oustanding questions, Genes Dev. 26 (3) (Feb 1 2012) 203-234, http://dx.doi.org/ 10.1101/gad.183434.111.

[3] M.S. Hayden, S. Ghosh, NF-kB Iin immunobiology, Cell Res. 21 (2) (Feb 2011) 223-244, http://dx.doi.org/10.1038/cr.2011.13

[4] S. Beinke, S.C. Ley, Functions of NF-kappaB1 and NF-kappaB2 in immune cell biology, Biochem. J. 382 (Pt 2) (Sep 1 2004) 393-409.

[5] M. Valle Blázquez, I. Luque, E. Collantes, E. Aranda, R. Solana, J. Peña, E. Muñoz, Cellular redox influences both cytotoxic and NF-kappa B activation in natural killer cells, Immunology 90 (3) (Mar 1997) 455-460.

[6] M.D. Jyothi, A. Khar, Interleukin-2 induced nitric oxide synthase and nuclear factor$\mathrm{kB}$ activity in activated natural killer cells and the production of Interferon- $\gamma$, Scand. J. Immunol. 52 (2) (Aug 2000) 148-155.

[7] C.M. Tato, N. Mason, D. Artis, S. Shapira, J.C. Caamano, J.H. Bream, H.C. Liou, C.A. Hunter, Opposing roles of NF-kappaB family members in the regulation of NK cell proliferation and production of IFN-gamma, Int. Immunol. 18 (4) (Apr 2006) 505-513.

[8] K.L. Willmann, S. Klaver, F. Doğu, E. Santos-Valente, W. Garncarz, I. Bilic, E. Mace, E. Salzer, C.D. Conde, H. Sic, P. Májek, P.P. Banerjee, G.I. Vladimer, S. Haskoloğlu, M.G. 
Bolkent, A. Küpesiz, A. Condino-Neto, J. Colinge, G. Superti-Furga, W.F. Pickl, M.C. van Zelm, H. Eibel, J.S. Orange, A. Ikincioğulları, K. Boztuğ, Biallelic loss-of-function mutation in NIK causes a primary immunodeficiency with multifaceted aberrant lymphoid immunity, Nat. Commun. 5 (Nov 19 2014) 5360, http://dx.doi.org/10. 1038/ncomms6360.

[9] J.S. Orange, S.R. Brodeur, A. Jain, F.A. Bonilla, L.C. Schneider, R. Kretschmer, S. Nurko, W.L. Rasmussen, J.R. Köhler, S.E. Gellis, B.M. Ferguson, J.L. Strominger, J. Zonana, N. Ramesh, Z.K. Ballas, R.S. Geha, Deficient natural killer cell cytotoxicity in patients with IKK-gamma/NEMO mutations, J. Clin. Invest. 109 (11) (Jun 2002) 1501-1509.

[10] C.E. Lee, D.A. Fulcher, B. Whittle, R. Chand, N. Fewings, M. Field, D. Andrews, C.C. Goodnow, M.C. Cook, Autosomal-dominant B-cell deficiency with alopecia due to a mutation in NFKB2 that results in nonprocessable p100, Blood 124 (19) (Nov 6 2014) 2964-2972.

[11] Y. Liu, S. Hanson, P. Gurugama, A. Jones, B. Clark, M.A. Ibrahim, Novel NFKB2 mutation in early-onset CVID, J. Clin. Immunol. 34 (6) (2014) 686-690.

[12] V. Lougaris, G. Tabellini, M. Vitali, M. Baronio, O. Patrizi, G. Tampella, A. Biasini, D. Moratto, S. Parolini, A. Plebani, Defective natural killer-cell cytotoxic activity in NFKB2-mutated CVID-like disease, J. Allergy Clin. Immunol. 135 (6) (Jun 2015) 1641-1643, http://dx.doi.org/10.1016/j.jaci.2014.11.038.

[13] M. Fliegauf, V.L. Bryant, N. Frede, C. Slade, S.T. Woon, K. Lehnert, S. Winzer, A. Bulashevska, T. Scerri, E. Leung, A. Jordan, B. Keller, E. de Vries, H. Cao, F. Yang, A.A. Schäffer, K. Warnatz, P. Browett, J. Douglass, R.V. Ameratunga, J.W. van der Meer, B. Grimbacher, Haploinsufficiency of the NF-kB1 subunit p50 in common variable immunodeficiency, Am. J. Hum. Genet. 97 (3) (Sep 3 2015) 389-403, http://dx.doi.org/10.1016/j.ajhg.2015.07.00.

[14] L. Moretta, Dissecting CD56dim human NK cells, Blood 116 (19) (Nov 11 2010) 3689-3691.

[15] V. Lougaris, D. Moratto, M. Baronio, G. Tampella, J.W. van der Meer, R. Badolato, M. Fliegauf, A. Plebani, Early and late B cell developmental impairment in NFKB1 mutated CVID disease. J. Allergy Clin. Immunol. (Jul 16 2016) http://dx.doi.org/10. 1016/j.jaci.2016.05.045 pii: S0091-6749(16)30628-5.

[16] B. Keller, Z. Cseresnyes, I. Stumpf, C. Wehr, M. Fliegauf, A. Bulashevska, S. Usadel, B. Grimbacher, M. Rizzi, H. Eibel, R. Niesner, K. Warnatz, Disturbed canonical NF-кB signaling in B cells of CVID patients, J. Allergy Clin. Immunol. (Jun 14 2016) http:// dx.doi.org/10.1016/j.jaci.2016.04.043 pii: S0091-6749(16)30441-9.

[17] M.A. Cooper, T.A. Fehniger, M.A. Caligiuri, The biology of human natural killer-cell subsets, Trends Immunol. 22 (2001) 633-640.

[18] A. Moretta, E. Marcenaro, S. Parolini, G. Ferlazzo, L. Moretta, NK cells at the interface between innate and adaptive immunity, Cell Death Differ. 15 (2) (Feb 2008) 226-233.

[19] S. Agaugué, E. Marcenaro, B. Ferranti, L. Moretta, A. Moretta, Human natural killer cells exposed to IL-2, IL-12, IL-18, or IL-4 differently modulate priming of naive T cells by monocyte derived dendritic cells, Blood 112 (5) (Sep 1 2008) 1776-1783.
[20] P.H. Kruse, J. Matta, S. Uglini, E. Vivier, Natural cytotoxicity receptors and their ligands, Immunol. Cell Biol. 92 (3) (Mar 2014) 221-229.

[21] M. Della Chiesa, L. Muccio, A. Moretta, CMV induces rapid NK cell maturation in HSCT recipients, Immunol. Lett. 155 (1-2) (Sep-Oct 2013) 11-13.

[22] H. Kared, S. Martelli, T.P. Ng, S.L. Pender, A. Larbi, CD57 in human natural killer cells and T-lymphocytes, Cancer Immunol. Immunother. 65 (4) (Apr 2016) 441-452.

[23] C. Bayard, H. Lepetitcorps, A. Roux, M. Larsen, S. Fastenackels, V. Salle, V. Vieillard, A Marchant, M. Stern, J. Boddaert, F. Bajolle, V. Appay, D. Sauce, Coordinated expansion of both memory T cells and NK cells in response to CMV infection in humans. Eur. J. Immunol. 46 (5) (May 2016) 1168-1179, http://dx.doi.org/10.1002/eji.201546179.

[24] A. Rölle, P. Brodin, Immune Adaptation to Environmental Influence: The Case of NK Cells and HCMV, Trends Immunol. 37 (3) (Mar 2016) 233-243, http://dx.doi.org/10. 1016/j.it.2016.01.005.

[25] K. Juelke, M. Killig, M. Luetke-Eversloh, E. Parente, J. Gruen, B. Morandi, G. Ferlazzo, A. Thiel, I. Schmitt-Knosalla, C. Romagnani, CD62L expression identifies a unique subset of polyfunctional CD56dim NK cells, Blood 116 (8) (Aug 26 2010) 1299-1307.

[26] E. de Valle, G. Grigoriadis, L.A. O'Reilly, S.N. Willis, M.J. Maxwell, L.M. Corcoran, E Tsantikos, J.K. Cornish, K.A. Fairfax, A. Vasanthakumar, M.A. Febbraio, M.L. Hibbs, M. Pellegrini, A. Banerjee, P.D. Hodgkin, A. Kallies, F. Mackay, A. Strasser, S. Gerondakis, R. Gugasyan, NFkB1 is essential to prevent the development of multiorgan autoimmunity by limiting IL-6 produiction in follicular B cells, J. Exp. Med. 213 (4) (Apr 4 2016) 621-641.

[27] H. Boztug, T. Hirschmugl, W. Holter, K. Lakatos, L. Kager, D. Trapin, W. Pickl, E. Förster-Waldl, K. Boztug, NF-kB1 haploinsufficiency causing immunodeficiency and EBV-driven lymphoproliferation, J. Clin. Immunol. 36 (6) (Aug 2016) 533-540, http://dx.doi.org/10.1007/s10875-016-0306-1.

\section{Further Reading}

[28] J.S. Orange, Natural killer cell deficiency, J. Allergy Clin. Immunol. 132 (3) (Sep 2013) 515-525.

[29] U. Pannicke, B. Baumann, S. Fuchs, P. Henneke, A. Rensing-Ehl, M. Rizzi, A. Janda, K Hese, M. Schlesier, K. Holzmann, S. Borte, C. Laux, E.M. Rump, A. Rosenberg, T. Zelinski, H. Schrezenmeier, T. Wirth, S. Ehl, M.L. Schroeder, K. Schwarz, Deficiency of innate and acquired immunity caused by an IKBKB mutation, N. Engl. J. Med. 369 (26) (Dec 26 2013) 2504-2514. 